\title{
Short communication: Weak associations between mastitis control measures and bulk milk somatic cell counts in Swedish dairy herds
}

\author{
U. Emanuelson* ${ }^{* 1}$ and C. Nielsen† \\ *Department of Clinical Sciences, Swedish University of Agricultural Sciences, Uppsala, SE-75007, Sweden \\ †Division of Occupational and Environmental Medicine, Lund University, Lund, SE-22100, Sweden
}

\begin{abstract}
Despite the fact that control programs have been available for several decades, mastitis remains an important problem in dairy herds around the world. Possible reasons for this include poor uptake and application of recommended mastitis control measures; poor or variable compliance; or variability in the effects of these measures. The objective of this study was to evaluate the associations between implemented mastitis control measures and bulk milk somatic cell count (BMSCC) in Swedish dairy herds. Data for this study were collected primarily from an extensive self-administered postal questionnaire about the herds, the people responsible for udder health, and details of udder health and mastitis management. A total of 898 questionnaires were distributed, and 428 questionnaires were returned (overall response rate of $48 \%$ ), but we used the information from only 395 herds in this study. For all herds, we collected data on herd size and geometric average calculated BMSCC from the Swedish Official Milk Recording Scheme. We used logistic regression to assess the association between mastitis control measures and BMSCC, dichotomized as low $(<200,000$ cells $/ \mathrm{mL})$ or high $(>200,000$ cells $/ \mathrm{mL})$. We investigated 21 measures that have been suggested for mastitis control, but found only 2 to be associated with udder health as measured by BMSCC. Not providing dry cows with a specialized mineral feed was significantly associated with increased risk of high BMSCC, and not using post-milking teat disinfectant tended to be associated with increased risk. The lack of association for all other measures was not likely due to low power (because most of these measures had variable implementation rates) but could be due to the relatively narrow range of BMSCC in our study (range 61,000-524,000 cells/mL). However, our results agreed well with those of other recent studies, supporting the call for a thorough review of the current
\end{abstract}

Received December 1, 2016.

Accepted April 25, 2017.

${ }^{1}$ Corresponding author: ulf.emanuelson@slu.se knowledge of mastitis control and for wider application of intervention studies to verify the actual effects of suggested control measures.

Key words: dairy cow, management, bulk milk somatic cell count

\section{Short Communication}

Mastitis in dairy cows is a major problem around the world, and many have attempted to develop mastitis control measures, including the 5-point plan of Dodd and Neave (1970) and the 10-point plan of the National Mastitis Council (https://www.nmconline.org). Common to all such plans is that costs are incurred in terms of increased labor, equipment, and consumables, so measures must have a positive return on investment if they are to be adopted to an appreciable degree. Estimates of the effect of different measures on mastitis rates are essential for evaluating their return on investment. Intervention studies are needed to evaluate the actual and realized effects of implemented control measures, but such studies are costly, and only a few have been performed (Green et al., 2007). The alternative is to compare the udder health of herds with and without implemented control measures, and several such studies have been performed (Dufour et al., 2011). However, most of the studies cited by Dufour et al. (2011) were performed during the last century, with different general udder health status and herd structures compared to today; it is therefore imperative to re-estimate associations under current conditions.

The objective of the present study was to determine the associations between implemented mastitis control measures and bulk milk SCC (BMSCC) in Swedish dairy herds, adjusting for potential confounders.

Data for this study were collected primarily from an extensive self-administered postal questionnaire sent in May 2011 to a sample of Swedish dairy farmers. The sample was drawn from the database of the Swedish Official Milk Recording Scheme, which was run at that time by the Swedish Dairy Association. Data were stratified by housing and milking system. All herds in Sweden with freestalls and an automatic milking sys- 
tem (AMS; $\mathrm{n}=298$ ) were eligible for inclusion in the study, and samples of 300 herds with tie stalls and pipeline milking and 300 herds with freestalls and parlor milking were identified by randomization from farms in the respective populations. We collected information about the herds and the people responsible for udder health, and the questionnaire also contained detailed questions about udder health and mastitis management. In total, the questionnaire had 9 pages and 23 questions; several questions also had sub-questions. Completion of the questionnaire was estimated to take approximately $30 \mathrm{~min}$. The question on applied mastitis control measures was "Which of the following measures are implemented in the herd?", followed by 21 control measures related to stall hygiene, milking hygiene and milking routines, dry-cow management, and general management routines (Table 1). Mailing and collection of the questionnaires was managed by Statistics Sweden (Statistiska Centralbyrån, Örebro, Sweden; www. scb.se). Pre-testing of the questionnaire was done by 2 researchers, 1 with experience in designing questionnaires and 1 with experience in mastitis research, and the questionnaire content was also reviewed for clarity by Statistics Sweden. The instructions provided with the questionnaire specifically requested that the person responsible for udder health in the herd answer the questionnaire. Further details about the questionnaire can be found in Nielsen and Emanuelson (2013).

For all herds, we obtained data on herd size and the geometric average calculated BMSCC for 2010 (the year to which the questions in the questionnaire applied) from the Swedish Official Milk Recording Scheme. The BMSCC was based on individual cow test-day information on milk yield and SCC, rather than on milk delivered.

We used logistic regression to assess the association between mastitis control measures and BMSCC, where BMSCC was classified as low $(<200,000$ cells/mL) or high $(>200,000$ cells $/ \mathrm{mL})$. Associations were evaluated 1 measure at a time, and then all measures with a $P$ value $<0.20$ were included in a multivariable model. We derived a final model by backward elimination, using a significance level of $10 \%$. Potentially confounding explanatory factors (i.e., milking system, herd size, sex of the individual responsible for udder health, and number of employees) were included in all models. We developed separate models as sensitivity analyses by (1) excluding herds with AMS, because some mastitis control measures could not be implemented in such herds, and (2) excluding the $10 \%$ of herds with the highest BMSCC $(>349,000$ cells $/ \mathrm{mL})$, because such herds might feel forced by dairy company restrictions to implement mastitis control measures so they could deliver milk.
The fit of the multivariable model was assessed with a Hosmer-Lemeshow goodness-of-fit test (Hosmer and Lemeshow, 2000), and the coefficient of determination with a generalized $\mathrm{R}^{2}$ as suggested by Nagelkerke (1991). All statistical analyses were performed using SAS (version 9.4; SAS Institute Inc., Cary, NC).

A total of 898 questionnaires were distributed, and 428 usable questionnaires were obtained (overall response rate of $48 \%$ ), but only 395 herds (i.e., herds with only 1 type of housing/milking system and with BMSCC available) were used in this study. A detailed description of the observations from the complete study can be found in Nielsen and Emanuelson (2013). The median (range) of BMSCC in herds classified as low was 176,000 (61,000-198,000) cells/mL and 265,000 $(200,000-524,000)$ cells $/ \mathrm{mL}$ in herds classified as high. The distribution of herds according to mastitis control measures and some potentially confounding variables is presented in Table 1, together with BMSCC for the subgroups. The median (range) BMSCC for quartiles of herd size were 221,000 (61,000-429,000), 240,000 $(96,000-506,000), \quad 241,000 \quad(68,000-465,000), \quad$ and $256,000(127,000-524,000)$ cells $/ \mathrm{mL}$, respectively, and the corresponding percentages in each quartile with BMSCC $<200,000$ cells $/ \mathrm{mL}$ were $32,27,25$, and $20 \%$. The most striking difference between herd types was the low proportion of low BMSCC among herds using AMS.

Results from the multivariable logistic regression model are presented in Table 2. Not providing dry cows with a specialized mineral feed was significantly associated with increased risk of the herd having a high BMSCC. Not using post-milking teat disinfectant tended to be associated with increased risk. The HosmerLemeshow goodness-of-fit statistic was not significant $(P=0.11)$, indicating a reasonable fit, although the model explained only $8 \%$ of the variation as assessed by generalized $\mathrm{R}^{2}$. When herds with AMS were excluded, the effect of the sex of the individual responsible for udder health became significant [odds ratio $(\mathbf{O R})=$ 2.53, 95\% CI: $1.36-4.71]$, the use of post-milking teat disinfectant became significant (OR 2.21, 95\% CI: 1.00-4.85), the OR for dry-cow mineral feed increased a small amount (OR 2.33, 95\% CI: 1.15-4.71), and the model fit improved (Hosmer-Lemeshow $P=0.75$ ), but no additional mastitis control measures were significantly associated with the outcome.

The only mastitis control measure significantly associated with BMSCC for all herds was providing dry cows with a mineral feed that covered their needs. This control measure was implemented in the majority of the herds (290/395), so it might have an important effect on udder health in Swedish dairy cows. Various feeding regimens have been found to be associated with udder 
Table 1. Descriptive statistics for 395 respondents to a postal questionnaire on mastitis management in Swedish dairy herds related to bulk milk SCC (BMSCC, $\times 10^{3}$ cells $\left./ \mathrm{mL}\right)$

\begin{tabular}{|c|c|c|c|c|c|}
\hline Variable & Level & $\mathrm{N}^{1}$ & $\begin{array}{c}\text { BMSCC } \\
<200,000 \\
\text { cells } / \mathrm{mL}, \%\end{array}$ & $P$-value ${ }^{2}$ & $\begin{array}{l}\text { BMSCC } \\
\text { median } \\
\text { (range) }\end{array}$ \\
\hline \multicolumn{6}{|l|}{ Potential confounders } \\
\hline \multirow{3}{*}{ Housing/milking system } & Freestall/parlor & 146 & 31 & 0.001 & $229(68-524)$ \\
\hline & $\begin{array}{l}\text { Freestall/automatic } \\
\text { milking system }\end{array}$ & 132 & 14 & & $262(129-465)$ \\
\hline & Tiestall/pipeline & 117 & 32 & & $230(61-448)$ \\
\hline \multirow[t]{2}{*}{ Sex of the person responsible for udder health } & Male & 270 & 24 & 0.23 & $247(61-506)$ \\
\hline & Female & 119 & 30 & & $229(104-524)$ \\
\hline \multirow[t]{3}{*}{ Employees } & $>1$ & 136 & 25 & 0.91 & $239(68-524)$ \\
\hline & 1 & 109 & 28 & & $251(96-480)$ \\
\hline & Only family & 146 & 26 & & $245(61-506)$ \\
\hline \multicolumn{6}{|l|}{ Mastitis control measures } \\
\hline \multirow{2}{*}{$\begin{array}{l}\text { Stalls cleaned and fresh bedding material provided } \\
\geq 2 \text { times per day }\end{array}$} & No & 39 & 18 & 0.24 & $265(127-524)$ \\
\hline & Yes & 356 & 27 & & $241(61-506)$ \\
\hline \multirow[t]{2}{*}{ Yards cleaned $\geq 2$ times per day } & No & 178 & 28 & 0.48 & $238(61-524)$ \\
\hline & Yes & 217 & 24 & & $244(68-506)$ \\
\hline \multirow{2}{*}{$\begin{array}{l}\text { Cows in milk grouped according to udder health } \\
\text { status }\end{array}$} & No & 252 & 23 & 0.05 & $250(96-524)$ \\
\hline & Yes & 143 & 31 & & $233(61-480)$ \\
\hline \multirow[t]{3}{*}{ Milkers' gloves used at every milking } & No & 142 & 30 & 0.001 & $226(61-506)$ \\
\hline & Yes & 122 & 33 & & $233(68-524)$ \\
\hline & Not relevant & 131 & 14 & & $262(129-465)$ \\
\hline \multirow{3}{*}{$\begin{array}{l}\text { Dirty udders washed with water and dried before } \\
\text { attaching the cluster }\end{array}$} & No & 159 & 31 & 0.001 & $230(61-524)$ \\
\hline & Yes & 105 & 32 & & $230(68-506)$ \\
\hline & Not relevant & 131 & 14 & & $262(129-465)$ \\
\hline \multirow{3}{*}{$\begin{array}{l}\text { Teats cleaned with } 1 \text { cloth per cow before attaching } \\
\text { the cluster }\end{array}$} & No & 32 & 28 & 0.001 & $228(115-480)$ \\
\hline & Yes & 232 & 32 & & $230(61-524)$ \\
\hline & Not relevant & 131 & 14 & & $262(129-465)$ \\
\hline \multirow[t]{3}{*}{ All cows prestripped } & No & 57 & 21 & 0.001 & $244(104-406)$ \\
\hline & Yes & 207 & 34 & & $225(61-524)$ \\
\hline & Not relevant & 131 & 14 & & $262(129-465)$ \\
\hline \multirow[t]{3}{*}{ Hard-milking cows stimulated manually during milking } & No & 168 & 29 & 0.001 & $226(68-524)$ \\
\hline & Yes & 96 & 25 & & $234(61-506)$ \\
\hline & Not relevant & 131 & 14 & & $262(129-465)$ \\
\hline \multirow[t]{2}{*}{ All cows treated with post-milking teat disinfectant } & No & 81 & 17 & 0.05 & $251(147-524)$ \\
\hline & Yes & 314 & 28 & & $241(61-506)$ \\
\hline \multirow{2}{*}{$\begin{array}{l}\text { Clusters rinsed with warm water after milking cows } \\
\text { with acute clinical mastitis }\end{array}$} & No & 205 & 26 & 0.99 & $240(61-480)$ \\
\hline & Yes & 190 & 26 & & $244(68-524)$ \\
\hline \multirow{2}{*}{$\begin{array}{l}\text { Clusters rinsed with warm water after milking cows } \\
\text { with high SCC }\end{array}$} & No & 270 & 26 & 0.95 & $242(61-524)$ \\
\hline & Yes & 125 & 26 & & $244(68-506)$ \\
\hline Cows with acute clinical mastitis milked last & No & 113 & 34 & 0.002 & $233(96-524)$ \\
\hline & Yes & 158 & 29 & & $230(61-480)$ \\
\hline & Not relevant & 124 & 15 & & $262(129-465)$ \\
\hline Cows with high SCC milked last & No & 115 & 30 & 0.001 & $225(96-524)$ \\
\hline & Yes & 151 & 32 & & $233(61-480)$ \\
\hline & Not relevant & 129 & 14 & & $262(129-465)$ \\
\hline Cows kept standing for $\geq 30$ min after milking & No & 228 & 31 & 0.007 & $230(61-524)$ \\
\hline & Yes & 54 & 28 & & $241(96-465)$ \\
\hline & Not relevant & 113 & 15 & & $262(150-454)$ \\
\hline Teat-cup liners replaced according to manufacturer's & No & 30 & 23 & 0.75 & $219(115-433)$ \\
\hline recommendations & Yes & 365 & 26 & & $244(61-524)$ \\
\hline Dry-cow therapy administered in consultation with & No & 117 & 22 & 0.29 & $259(68-454)$ \\
\hline veterinarian & Yes & 278 & 27 & & $240(61-524)$ \\
\hline Dry cows fed a mineral feed that covered their needs & No & 105 & 17 & 0.02 & $262(61-524)$ \\
\hline & Yes & 290 & 29 & & $240(68-506)$ \\
\hline Dry cows grouped according to udder health status & No & 367 & 25 & 0.43 & $242(61-524)$ \\
\hline & Yes & 28 & 32 & & $250(142-395)$ \\
\hline Calvings in single pens cleaned between animal & No & 197 & 27 & 0.62 & $239(61-524)$ \\
\hline occupations & Yes & 198 & 25 & & $249(96-506)$ \\
\hline Udder health status of the herd regularly discussed & No & 262 & 26 & 0.93 & $246(68-524)$ \\
\hline with a veterinarian & Yes & 133 & 26 & & $234(61-465)$ \\
\hline Feeding plans continuously reviewed and revised & No & 54 & 24 & 0.75 & $256(96-454)$ \\
\hline when needed & Yes & 341 & 26 & & $241(61-524)$ \\
\hline
\end{tabular}

${ }^{1}$ Number of respondents.

${ }^{2}$ Chi-squared test comparing the distribution of herds with BMSCC $<200,000$ cells $/ \mathrm{mL}$. 
Table 2. Results from the multivariable logistic regression model of risk factors associated with herds with high bulk milk SCC ( $>200,000$ cells/ $\mathrm{mL})$

\begin{tabular}{|c|c|c|c|c|c|c|}
\hline Variable & Level & Estimate & $\mathrm{SE}$ & $P$-value & Odds ratio & $95 \% \mathrm{CI}$ \\
\hline Intercept & & 1.06 & 0.48 & - & - & - \\
\hline \multirow[t]{3}{*}{ Housing/milking system } & Freestall/parlor & -0.04 & 0.32 & 0.002 & 0.96 & $0.52-1.78$ \\
\hline & $\begin{array}{l}\text { Freestall/automatic milking } \\
\text { system }\end{array}$ & 1.05 & 0.34 & - & 2.86 & $1.46-5.60$ \\
\hline & Tiestall/pipeline & Baseline & - & - & 1 & - \\
\hline \multirow{2}{*}{$\begin{array}{l}\text { Sex of the person responsible } \\
\text { for udder health }\end{array}$} & Male & 0.50 & 0.27 & 0.065 & 1.64 & $0.97-2.78$ \\
\hline & Female & Baseline & - & - & 1 & - \\
\hline \multirow[t]{3}{*}{ Employees } & $>1$ & 0.06 & 0.34 & - & 1.06 & $0.55-2.05$ \\
\hline & 1 & -0.05 & 0.30 & 0.953 & 0.95 & $0.53-1.73$ \\
\hline & Only family & Baseline & - & - & 1 & - \\
\hline Herd size & Continuous & 0.004 & 0.002 & 0.098 & $1.04^{1}$ & 0.99-1.09 \\
\hline \multirow[t]{2}{*}{ Post-dip ${ }^{2}$} & No & 0.59 & 0.34 & 0.078 & 1.81 & $0.93-3.50$ \\
\hline & Yes & Baseline & - & - & 1 & - \\
\hline \multirow[t]{2}{*}{ Minerals $^{3}$} & No & 0.77 & 0.31 & 0.012 & 2.16 & $1.12-4.18$ \\
\hline & Yes & Baseline & - & - & 1 & - \\
\hline
\end{tabular}

${ }^{1}$ Per 10-unit increase in number of cows.

${ }^{2}$ All cows treated with post-milking teat disinfectant.

${ }^{3}$ Dry cows fed a mineral feed that covers their needs.

health, but, as pointed out by Dufour et al. (2011), the actual effect of feeding a specific type of feed is determined by the composition of the total diet and by the status of the herd for the nutrient in question. The association we found might not be applicable under all intensive dairy production conditions, although we do know that the feed given to dry cows is important for their health when they are in transition, and that a large proportion of mastitis cases occur close to calving. Proper mineral feeding of dry cows might thus be a proxy for good general herd management. However, we found no associations between mineral feeding and other management-related information such as on-farm mortality, reproductive performance, or urea content in milk (data not shown), so this probably does not explain the association.

We also found that treating all cows with postmilking teat disinfectant decreased the odds of a herd having high BMSCC, especially for non-AMS herds. Post-milking teat dipping was one of the few mastitis control measures that had a consistent association with udder health in the review by Dufour et al. (2011), so this seems to be a measure worth applying in all herds. Wearing milkers' gloves, using automatic milking unit take-offs, applying a milking order based on udder health, performing a yearly inspection of the milking system, and keeping cows standing after milking have also been shown to have consistent associations with udder health (Dufour et al., 2011), but we found no such associations. The lack of association was not likely due to low power, because most of the measures had variable implementation rates, but it might have been due to the relatively narrow range in BMSCC in the present study.
Many of the mastitis control measures we investigated cannot be implemented in herds using AMS, the reason for many of the "not relevant" replies in Table 1. [The distribution of control measures according to housing/milking system can be found in Nielsen and Emanuelson (2013).] We therefore explored whether excluding AMS herds from the analysis changed the associations, but the results were basically the same, and we identified no new associations; this finding suggests that the results were robust. The 2 control measures associated with BMSCC in both analyses could also be applied in herds that use AMS.

A cross-sectional study such as ours cannot establish causal associations, because the time sequence of events is unknown. Herds with poor udder healthand thus very high BMSCC - are more likely to apply measures because they feel compelled to; in a study such as ours, higher use in these herds can make it seem as if a higher risk of poor health is associated with mastitis control measures. We tried to minimize this effect by looking at BMSCC in low and high categories rather as a continuous variable, reducing the effect of herds with exceedingly poor udder health. Thus, the majority of herds that belonged to the high BMSCC group were not likely to have been "forced" to use mastitis control measures, reducing the leverage on the associations of herds with poor udder health. To further limit the effect of herds with poor udder health, we excluded the $10 \%$ of herds with the highest BMSCC, and the results remained basically the same (not shown). The results remained also basically the same (not shown; feeding dry cow minerals as the only significant effect) when we included only herds with BMSCC $<200,000$ cells $/ \mathrm{mL}$ and $>300,000$ cells $/ \mathrm{mL}$ in 
the analysis, showing that the results were robust for the modeling approach.

We investigated 21 measures that have been suggested for mastitis control, but found only 2 of them to be associated with udder health measured as BMSCC. This finding was consistent with the study of Schewe et al. (2015), who also found that none of several mastitis control measures - except for the use of internal teat sealant (at dry-off) - was associated with lower BMSCC. Our findings also agreed well with the lack of consistency identified by Dufour et al. (2011), who found that "relatively few of the numerous management practices investigated demonstrated consistent associations with SCC." These observations point to the need for a thorough review of the current knowledge of mastitis control and for a wider application of intervention studies.

\section{ACKNOWLEDGMENTS}

The authors gratefully acknowledge funding for this project from the Swedish Research Council Formas (Stockholm).

\section{REFERENCES}

Dodd, F. H., and F. K. Neave. 1970. Mastitis control. Pages 21-60 in Biennial Reviews 1970. National Institute for Research in Dairying, Shinfield, UK.

Dufour, S., A. Fréchette, H. W. Barkema, A. Mussell, and D. T. Scholl. 2011. Invited review: Effect of udder health management practices on herd somatic cell count. J. Dairy Sci. 94:563-579.

Green, M. J., K. A. Leach, J. E. Breen, L. E. Green, and A. J. Bradley 2007. National intervention study of mastitis control in dairy herds in England and Wales. Vet. Rec. 160:287-293.

Hosmer, D. W., Jr., and S. Lemeshow. 2000. Applied Logistic Regression, Second ed. John Wiley \& Sons, New York, NY.

Nagelkerke, N. J. D. 1991. A note on a general definition of the coefficient of determination. Biometrika 78:691-692.

Nielsen, C., and U. Emanuelson. 2013. Mastitis control in Swedish dairy herds. J. Dairy Sci. 96:6883-6893.

Schewe, R. L., J. Kayitsinga, G. A. Contreras, C. Odom, W. A. Coats, P. Durst, E. P. Hovingh, R. O. Martinez, R. Mobley, S. Moore, and R. J. Erskine. 2015. Herd management and social variables associated with bulk tank somatic cell count in dairy herds in the eastern United States. J. Dairy Sci. 98:7650-7665. 